\title{
CRENÇA TEÍSTA E EVOLUÇÃO: UMA ABORDAGEM A PARTIR DE ALVIN PLANTINGA
}

Theistic belief and evolution: an approach from Alvin Plantinga

Welinton Ricardo da Silveira Porto *

Resumo: Este artigo analisa a crítica de Alvin Plantinga ao naturalismo presente na psicologia evolutiva e verifica se a teoria da dupla herança responde adequadamente à questão da confiabilidade de nossas faculdades cognitivas. Plantinga defende que a associação do naturalismo com a evolução é prejudicial à ciência, devido ao estabelecimento de um conflito profundo entre naturalismo e ciência por causa, entre outras coisas, da suspeita que tal associação traz com respeito as nossas faculdades cognitivas. Por outro lado, ele defende um acordo profundo entre ciência e religião, em razão de o teísmo não se comprometer com o naturalismo, garantindo a confiabilidade em tais faculdades.

Palavras-chave:

Naturalismo. Teísmo. Evolução. Faculdades

\begin{abstract}
This paper analyzes Alvin Plantinga's review to the naturalism present in evolutionary psychology and verifies whether the Dual Inheritance Theory suitably responds to the matter of reliability of our cognitive faculties. Plantinga defends that the association of naturalism and evolution is science harmful on account of the establishment of a deep conflict between naturalism and science, because - among other things - of the suspect that this association brings concerning to our cognitive faculties. On the other hand, he defends a deep agreement between science and religion, due to the theism is not committed with naturalism, ensuring the reliability of such faculties.
\end{abstract}

Key-Words: Naturalism. Theism. Evolution. Cognitive Faculties.

Cognitivas.

\footnotetext{
* Professor do Centro Filosófico-teológico Redemptoris Mater de Brasília (Instituto afiliado à Pontificia Università Lateranense) Email: welintonporto@gmail.com
}

\begin{tabular}{|c|c|l|l|l|l|}
\hline intuitio & $\begin{array}{c}\text { ISSN } \\
1983-4012\end{array}$ & Porto Alegre & Vol. $8-\mathrm{N}^{\circ} .1$ & $\begin{array}{c}\text { Junho } \\
2015\end{array}$ & p.261-275 \\
\hline
\end{tabular}




\section{Introdução}

O objetivo deste trabalho é contribuir na discussão existente entre "ciência x naturalismo" e "religião x ciência", conforme a análise oferecida por Alvin Plantinga (1932-), restringindo-nos aos aspectos da psicologia evolutiva e da conjunção entre naturalismo e evolução. Assim, trataremos primeiramente da argumentação de Plantinga frente à psicologia evolutiva, abordando a sua consequente defesa da crença teísta e mostrando que há um conflito meramente superficial entre religião e ciência. Essa análise será sofisticada com alguns elementos da teoria da dupla herança (Dual Inheritance Theory), com o intuito de robustecer o argumento de Plantinga contra o naturalismo. Por fim, passaremos ao argumento de Plantinga sobre a conjunção entre naturalismo e ciência, onde se mostrará que tal imbricação resulta em um conflito profundo. Este itinerário visa para responder às perguntas: I) se a teoria da dupla herança tem recursos suficientes que permitam a abordagem da psicologia evolutiva em estrutura conceitual. II) verificar se o argumento provido por Plantinga em favor do teísmo mantém-se plausível frente aos novos elementos introduzidos pela teoria da dupla herança.

Em Where The Conflict Really Lies (2011) ${ }^{1}$, Plantinga investiga a hipótese de um conflito entre ciência e crença teísta - mais especificamente, entre teoria da evolução e crença teísta. Os defensores de tal conflito afirmam que a ciência, no mínimo, põe em dúvida a ação de Deus no mundo - o bastante para se estabelecer uma espécie de conflito. Plantinga considera isso um engano, pois, apesar de a ação de Deus no mundo ter uma probabilidade mínima, há a possibilidade de Deus ter criado o mundo e os seres humanos com os recursos do processo evolutivo. De fato, é possível afirmar que o processo evolutivo é cego, não guiado por um ser pessoal qualquer, sendo assim desnecessária a postulação de um Deus criador e regente do mundo ${ }^{2}$. Contudo, caso a interrogação repouse sobre se o processo é ou não guiado, isso já não seria um conflito entre ciência e religião, mas sim um conflito ou um problema entre duas teses metafísicas, que culminaria na pergunta sobre a existência ou não de um Deus criador. Nesse sentido, religião e ciência seriam perfeitamente conciliáveis entre si.

Entretanto, há determinadas áreas do conhecimento científico em que podemos afirmar um real conflito. Plantinga afirma que tanto na psicologia evolutiva quanto na crítica bíblico-histórica o conflito entre religião e ciência se sustenta na medida em que há afirmações simultaneamente incompatíveis entre religião e ciência ${ }^{3}$. Não obstante, esse conflito é meramente superficial, visto que as teses de tais ciências

\footnotetext{
${ }^{1}$ Há outras obras em que Plantinga $(1991 ; 1993 ; 2002 ; 2011 ; 2014)$ trata desta relação entre ciência e religião, especialmente naquilo que se refere à associação entre naturalismo e evolução. Preferi restringir-me à Plantinga (2011) por considerar esta exposição razoavelmente adequada e completa para os propósitos deste artigo.

${ }^{2}$ Para melhor entendimento sobre o processo evolutivo cego, O Relojoeiro Cego de Richard Dawkins é uma boa referência inicial.

${ }^{3}$ Trataremos aqui somente dos aspectos voltados para a psicologia evolutiva, deixando a crítica bíblico-histórica para outro momento.
}

\begin{tabular}{|c|c|c|c|c|c|}
\hline intuitio & $\begin{array}{c}\text { ISSN } \\
1983-4012\end{array}$ & Porto Alegre & Vol.8 $-\mathrm{N}^{\mathrm{o}} .1$ & $\begin{array}{c}\text { Junho } \\
2015\end{array}$ & p.261-275 \\
\hline
\end{tabular}


são incapazes de gerar anuladores (defeaters) para a crença teísta. É sabido que a psicologia evolutiva procura descrever certas atitudes humanas (arte, religião, moralidade, etc.) com base em métodos que adotem um compromisso ontológico naturalista. A religião estabelece-se sobre uma base indicial ${ }^{4}$ mais extensa, onde entidades sobrenaturais atuam no mundo. Dadas essas considerações, veremos que a conclusão de Plantinga declina para a existência 1) de um acordo profundo entre religião e ciência e 2) de um conflito profundo entre ciência e naturalismo.

Ademais, a teoria da dupla herança, como uma descrição da Filosofia da Biologia a respeito de aspectos que anteriormente estavam reservados às ciências sociais e à psicologia, também aborda e avalia atitudes humanas (arte, religião, humor, poesia, moralidade, etc.) com base em um método naturalista, onde o viés metodológico leva em conta a coevolução gene-cultura. Tal teoria, como veremos, sofistica as teses defendidas pela psicologia evolutiva. Assim, depois de apresentada a psicologia evolutiva, passaremos à abordagem da teoria da dupla herança, para por em questão a defesa do teísmo provida por Plantinga.

\section{A psicologia evolutiva}

A psicologia evolutiva ${ }^{5}$ (doravante PE) é um ramo da psicologia que adota o aparato teórico darwinista na tentativa de explicar importantes traços e comportamentos humanos, em termos da origem evolutiva da espécie humana. Nesse tipo de proposta, a explicação de fenômenos como arte, humor, comportamento sexual, amor, poesia, música, moralidade, religião (os quais outrora restritos às ciências não-naturais ${ }^{6}$ ) passaria a ser abordada com o rigor das ciências naturais. Para tanto, a biologia seria a ciência responsável por essa tradução entre o natural e o não-natural, em que todo esse conjunto de fenômenos estaria dentro de um processo histórico-evolutivo, consequência de vantagens adaptativas de nossos ancestrais. Assim, o maravilhar-se com o belo (uma paisagem de por de sol, por exemplo) seria apenas parte de um processo cuja função é buscar vantagens adaptativas e transmitir carga genética aos descendentes. Ao que nos interessa (o fenômeno religioso) a PE formularia a uma série de argumentos a

\footnotetext{
${ }^{4}$ Por base indicial, entenderemos os indícios ou o conhecimento prévio que dispomos (conhecimento de fundo), os quais servem de subsídio para avaliarmos se uma crença atual $c$ é ou não plausível.

${ }^{5}$ Há, em vários artigos, a tradução "psicologia evolucionista" para "Evolutionary Psysicology", isso para não confundir com o termo "Psicologia Evolutiva" (estágios do desenvolvimento), que está ligado às ideias de J. Piaget (FLAVELL, 1991). Aqui, preferimos usar a tradução "psicologia evolutiva" por melhor se adequar à língua portuguesa, embora não estejamos nos referindo às ideias de Piaget, mas si ao termo "Evolutionary Psysicology".

${ }^{6}$ Por "ciências não-naturais", entendo todas as ciências (psicologia, sociologia, antropologia, ciências sociais, dentre outras) que não adotam as explicações tipicamente científicas. Para uma boa abordagem do tema "explicação científica", coferir o texto, organizado por David-Hillel Ruben (2004).
}

\begin{tabular}{|c|c|l|l|l|l|}
\hline intuitio & $\begin{array}{c}\text { ISSN } \\
1983-4012\end{array}$ & Porto Alegre & Vol.8 $-\mathrm{N}^{\mathrm{o}} .1$ & $\begin{array}{c}\text { Junho } \\
2015\end{array}$ & p.261-275 \\
\hline
\end{tabular}


fim de construir objeções vigorosas contra a religião. Plantinga faz uma varredura das diversas teorias da PE, respondendo a cada uma adequadamente ${ }^{7}$.

Alguns psicólogos evolutivos (D. S. Wilson, Steven Pinker, Podney Stark, Pascal Boyer e Scott Atran - citados ao longo desta seção) consideram a religião como uma grande exultação que os seres humanos celebram, em virtude da mudança de status de presa para o de predador. Embora essa pareça ser uma explicação razoável, ela é pouco plausível, haja vista permanecer em aberto a pergunta sobre quais as causas e quais as razões de o ser humano possuir uma religiosidade quando ainda em seu estado de presa. A PE recente não seguirá estritamente esse programa de pesquisa, mas defenderá que a religião é resultado de uma ilusão advinda de algum evento histórico-evolutivo específico. Contudo, há quem defenda ${ }^{8}$ que tal ilusão ajudaria no processo evolutivo, pois contribuiria na sobrevivência e no melhoramento de nossa aptidão. Assim, malgrado tais crenças não sejam verdadeiras, aqueles que elevam a aptidão (fitness) estariam mais bem preparados no ambiente onde vivem. Um grupo que tem uma religião competirá, possivelmente, melhor do que outro que não tem nenhuma. Nesse tipo de argumentação, percebe-se uma defesa em favor de uma ética naturalizada. Foi nesse viés que autores como M. Ruse \& E. O. Wilson (1993) entenderam a ética como uma ilusão decorrente da ação de nossos genes, os quais estariam determinados a maximizar a cooperação grupal. Assim, os organismos que melhor tivessem essa intuição moral, mais provavelmente transmitiriam sua herança genética, em razão da cooperação grupal. $\mathrm{O}$ resultado disso é que não haveria uma obrigação moral objetiva, mas sim um funcionamento dos genes que permitiria aos seres humanos imaginar a "existência" de tal obrigação".

Plantinga argumenta que mesmo sendo possível esse conceito funcional da moralidade, tal proposta não é capaz de responder ao fenômeno do altruísmo. Dirá ele, como explicar o altruísmo de pessoas como madre Teresa de Calcutá, do missionário escocês Eric Liddel, ou dos jesuítas do século XVII, os quais diminuíram suas aptidões individuais em benefício de outros? O natural, segundo a teoria da evolução, seria sempre aumentar as chances de sobrevivência e facilitar a perpetuação dos genes, ou seja, aumentar a aptidão individual no decorrer da corrida evolutiva. Outros pensadores, como Hebert Simon, propõem uma explicação do altruísmo em que dois mecanismos seriam determinantes para o comportamento humano. O primeiro desses mecanismos seria o que ele chama de "docilidade", cujo significado é a característica própria dos humanos acreditarem ou aprenderem algo que lhes são transmitidos. O segundo seria a "racionalidade limitada", uma disposição natural que temos em não avaliar se determinado comportamento aumentaria ou diminuiria nossa aptidão individual frente à do grupo. Esse tipo de raciocínio mostra-se insuficiente quando, por exemplo, perguntamos se seria correto

\footnotetext{
${ }^{7}$ PLANTINGA, A. Where The Conflict Really Lies. New York: OUP, 2011, p. 131.

${ }^{8}$ WILSON, D. S. Darwin's Cathedral: Evolution, Religion, and The Nature of Society. University of Chicago, 2010 [livro digital].

${ }^{9}$ PLANTINGA, A. Where The Conflict Really Lies. New York: OUP, 2011, p. 132-134.
}

\begin{tabular}{|c|c|l|l|l|l|}
\hline intuitio & $\begin{array}{c}\text { ISSN } \\
1983-4012\end{array}$ & Porto Alegre & Vol.8 $-\mathrm{N}^{\mathrm{o}} .1$ & $\begin{array}{c}\text { Junho } \\
2015\end{array}$ & p.261-275 \\
\hline
\end{tabular}


afirmar que um cristão pensaria assim de madre Teresa? A resposta mais comum seria a de que Madre Teresa agiu como agiu por razões espirituais, por que sentira um suposto amor de Deus, por que se compadeceu dos sofrimentos alheios, etc.; e não em virtude de uma docilidade e de uma racionalidade limitada ${ }^{10}$.

Outra forma de ver o fenômeno religioso seria, conforme Steven Pinker (1998), a de que as pessoas recorrem à religião quando acabam as técnicas usuais de resolver problemas. Assim, quando acabam os recursos oriundos da medicina, das estratégias, da arte de cortejar, das ciências em geral, o ser humano recorre à religião, a fim de justificar ou acalentar os seus sofrimentos e a falta de sentido da vida. Plantinga observar que explicações desse tipo mais se assemelham a uma aversão pessoal do que propriamente pronunciamentos científicos ou semi-científicos. A Psicologia, como uma ciência, não poderia então responder a fenômenos religiosos com esse tipo de argumentação ${ }^{11}$.

Das objeções apresentadas pela PE, a que nos parece mais forte é a que identifica religião como uma espécie de spandrels ${ }^{12}$ do pensamento racional. Autores como Rodney Stark (2009), Pascal Boyer (2001), Scott Atran (2006) consideram que a religião é um tipo de subproduto decorrente da evolução da nossa capacidade pensar. Assim, a religião seria apenas uma consequência (ou um "efeito colateral") haja vista o tipo de cérebro que atualmente temos. Dado o tipo de cérebro próprio dos seres humanos, naturalmente a religião se apresenta. Na verdade, nosso cérebro desenvolveu-se por meio da seleção natural, porém a religião em si mesma não seria adaptativa, mas apenas um subproduto de nossa arquitetura cognitiva. Ora, se de fato a religião é um subproduto, isso implica muitas vezes em prejuízo para os seres humanos como, por exemplo, gasto de tempo com orações, incitamento do medo e de certas esperanças vãs ou irrealizáveis. Somado a isso, a religião está recheada de noções e objetos contra-factuais e contra-intuitivos, como agentes sobrenaturais, salvação da "alma" pós-morte, ressurreição de Cristo, dentre outros. Com base em todas essas considerações, a PE deduz a falsidade da religião ${ }^{13}$.

Para Plantinga, não há nada nesses autores que seja inconsistente ou incompatível com o teísmo ou a crença cristã, visto que eles (autores) podem apenas afirmar uma origem natural da religião, afirmação esta que de modo algum anularia as crenças teístas, pois que Deus poderia ter criado nossas faculdades cognitivas segundo o processo evolutivo de maneira tal que nos permite ter o tipo de crença que temos. A conclusão que Plantinga chega é que todas essas teorias levantam sim certo conflito com a religião, entretanto tal conflito não constitui um problema sério entre religião e ciência, mas meramente superficial - pois a hipótese da ação de Deus no mundo não é anulada, mesmo se todas essas teorias

\footnotetext{
${ }^{10}$ PLANTINGA, A. Where The Conflict Really Lies. New York: OUP, 2011, p. 135-136.

${ }^{11}$ PLANTINGA, A. Where The Conflict Really Lies. New York: OUP, 2011, p. 137.

${ }^{12}$ Para uma abordagem mais detalhada sobre o significado de spandrels, conferir o artigo de GOLD, S. J.; LEWONTIN, R. C. "The Spandrels of San Marco and the Panglossian Paradigm: A Critique of the Adaptationist Programme". In: Proc. R. Soc. B, London, n. 205, 1979, p. 581-598.

${ }^{13}$ PLANTINGA, A. Where The Conflict Really Lies. New York: OUP, 2011, p. 137-139.
}

\begin{tabular}{|c|c|c|c|c|c|}
\hline intuitio & $\begin{array}{c}\text { ISSN } \\
1983-4012\end{array}$ & Porto Alegre & Vol.8 $-\mathrm{N}^{\mathrm{o} .1}$ & $\begin{array}{c}\text { Junho } \\
2015\end{array}$ & p.261-275 \\
\hline
\end{tabular}


fossem verdadeiras. Não somente, Plantinga passa a advogar que o cientista que acolhe a hipótese teísta mostra-se mais coerente do que o cientista naturalista, tendo em vista o teísmo adotar uma base indicial mais abrangente ${ }^{14}$.

É perfeitamente possível que um cristão cientista utilize-se do naturalismo metodológico. Um cientista cristão poderia dizer que quando ele faz ciência precisa ser imparcial e, por isso, utiliza-se do naturalismo metodológico ${ }^{15}$. Se isso é verdadeiro, o que então anularia uma crença religiosa? Ora, a PE está apenas em conflito superficial com a religião, o que significa que ela não provê anuladores ${ }^{16}$ cabais para a crença teísta. Contudo, essa linha de argumentação pouco contribui para a fundamentação da crença teísta. É preciso que o teísmo formule uma defesa não apenas recalcitrante, mas também justificável, a qual possa fazer frente à posição naturalista da ciência ${ }^{17}$. A pergunta geral que se impõe é o que então daria a uma crença motivos fortes para acreditarmos nela?

Plantinga dirá que o conhecimento de fundo que eu tenho para avaliar se uma determinada hipótese é ou não plausível é o método mais adequado na avaliação de crenças. Como ele argumenta se, por exemplo, diante da hipótese de um mordomo ter praticado um assassinato, tenho como conhecimento de fundo que ele não estava presente na cena do crime e tampouco poderia estar lá; esse contexto leva-me a crer que a hipótese de ele ter praticado o crime é falsa. A esse conhecimento de fundo Plantinga denomina de base indicial ${ }^{18}$. Ora, uma base indicial pode ser tanto natural como não-natural. Destarte, é fácil observar que a indicial de um cientista naturalista será incompatível com a base indicial do cientista cristão. Assim, Plantinga afirma ser preciso investigar se a imbricação ciência-naturalismo é ou não necessária e se tal conjunção é prejudicial à ciência ${ }^{19}$.

Adiante, veremos se a teoria da dupla herança pode acrescentar algo de novo a nossa discussão e verificar até que ponto ela resiste ao argumento de Plantinga em favor do teísmo.

\footnotetext{
${ }^{14}$ PLANTINGA, A. Where The Conflict Really Lies. New York: OUP, 2011, p. 139-140.

${ }^{15} \mathrm{O}$ naturalismo metodológico é uma espécie de suspensão de juízos, estabelecendo certas imposições ou limitações à ciência. Para o naturalismo metodológico, a ciência deve proceder como se não existissem entidades e bens sobrenaturais, tais como Deus, demônios, anjos, salvação, vida eterna, etc. Este tipo de naturalismo é diferente de outro, chamado de naturalismo ontológico, o qual afirma categoricamente que não há seres sobrenaturais, tampouco bens dessa seara.

${ }^{16}$ Por anuladores, entenderemos como uma crença específica $C_{2}$ que substitui outra crença $C_{1}$, em razão desta última ser tida como irracional por evidências atuais. Os exemplos de enganos visuais ilustram bem esse conceito. Uma pessoa que, ao ver um homem de longe (o qual se pareça muito com seu pai), adota a crença $\left(C_{l}\right)$ de que "tal homem é o meu pai". Contudo, ao se aproximar, ver e passa a acreditar $\left(C_{2}\right)$ que "este homem não é o meu pai". Caso continue a sustentar $C_{1}$ (ou seja, rejeitar o anulador), estará essa pessoa comportando-se de modo irracional.

${ }^{17}$ PLANTINGA, A. Where The Conflict Really Lies. New York: OUP, 2011, p. 163-164.

18 A base indicial do cristianismo inclui crença em Deus, encarnação do filho de Deus, ação divina no mundo (milagres), etc.

${ }^{19}$ PLANTINGA, A. Where The Conflict Really Lies. New York: OUP, 2011, p. 167.
}

\begin{tabular}{|c|c|c|c|c|c|}
\hline intuitio & $\begin{array}{c}\text { ISSN } \\
1983-4012\end{array}$ & Porto Alegre & Vol.8 $-\mathrm{N}^{\circ} .1$ & $\begin{array}{c}\text { Junho } \\
2015\end{array}$ & p.261-275 \\
\hline
\end{tabular}




\section{Teoria da dupla herança}

O objetivo desta parte é comparar a teoria da dupla herança (doravante TDH) com o que vimos na psicologia evolutiva a respeito de um juízo naturalista do comportamento humano e, a partir disso, dispor de um diagnóstico que identifique uma relação entre essas duas descrições, porém, tendo a TDH como proposta mais sofisticada. Segundo a TDH, explicações como as da PE, as quais invocam os genes e o ambiente como causas únicas para o comportamento humano, parecem insuficientes. É nesse sentido que Abrantes \& Almeida consideram como fundamento central da TDH a hipótese de a mente humana ser resultado de um processo evolutivo, onde se fazem presentes tanto forças genéticas quanto forças culturais. Nesse sentido, a cultura se identificaria com a "informação armazenada nos cérebros de seres humanos, adquirida por meio de mecanismos de aprendizagens social (imitação, ensino) e individual (observação)" ${ }^{20}$. Se tomarmos a cultura como informação, é possível tratarmos as variantes culturais em termos populacionais, ou seja, dispormos da possibilidade de "rastrear a mudança na proporção de cada variante no conjunto ( $p o o l$ ) de variantes culturais existentes em cada dada população em certo instante de tempo" 21 . Portanto, é-se possível falar de uma evolução cultural, haja vista variantes culturais presentes em determinada cultura modificarem ao longo do tempo, fato este explicado pela estrutura psicofísica de nossa espécie "ser capaz de aprender, transmitir e acumular variantes culturais" - semelhantemente à herança genética. Dirão Abrantes \& Almeida sobre isso:

Assim como ocorre na evolução com base em herança genética, o surgimento de variantes culturais complexas é explicado como o resultado de um longo processo de acumulação de pequenas e graduais variações, que envolvem várias gerações de indivíduos ${ }^{22}$.

Ora, para os biólogos, duas causas são consideradas importantes: a causa próxima e a causa última. A cultura humana, ao fim e ao cabo, perfaz tanto a causa próxima do nosso comportamento, mediada pela nossa psicologia, bem como a causa última, a evolução interagindo com nossa psicologia ${ }^{23}$. Destarte, podemos estabelecer uma primeira diferença entre PE e TDH, em que a primeira tem uma abordagem restrita à evolução genética, de modo que o comportamento humano seria uma consequência indireta do processo evolutivo genético e, portanto, explicável unicamente por este; enquanto que a última adota o conceito de acumulação cultural, estruturada pela imitação fidedigna (capacidade para imitar ou

${ }^{20}$ ABRANTES, P. C. C.; ALMEIDA, F. P. L. de. "A teoria da dupla herança e a evolução da moralidade”. In: Principia, Florianópolis, Vol. 16, n. 1, pp. 1-32, abr. 2012, p. 9.

${ }^{21}$ ABRANTES, P. C. C.; ALMEIDA, F. P. L. de. "A teoria da dupla herança e a evolução da moralidade". In: Principia, Florianópolis, Vol. 16, n. 1, pp. 1-32, abr. 2012, p. 9.

${ }^{22}$ ABRANTES, P. C. C.; ALMEIDA, F. P. L. de. "A teoria da dupla herança e a evolução da moralidade". In: Principia, Florianópolis, Vol. 16, n. 1, pp. 1-32, abr. 2012, p. 8-11.

${ }^{23}$ ABRANTES, P. C. C.; ALMEIDA, F. P. L. de. "Evolução humana: a teoria da dupla herança". In: ABRANTES, P. C. C. (org.). Filosofia da Biologia. Porto Alegre: Artmed, 2011, p. 262.

\begin{tabular}{|c|c|l|l|l|l|}
\hline intuitio & $\begin{array}{c}\text { ISSN } \\
1983-4012\end{array}$ & Porto Alegre & Vol.8 $-\mathrm{N}^{\circ} .1$ & $\begin{array}{c}\text { Junho } \\
2015\end{array}$ & p.261-275 \\
\hline
\end{tabular}


aprender coisas dos outros: aprendizagem social). Assim, a acumulação cultural dar-se por retroalimentação de nossa psicologia - em razão da aprendizagem social - onde atuariam a causa próxima (influência da cultura em nossa psicologia) e a causa última (influência da evolução genética no comportamento e na psicologia). A conclusão que se chega é de que a distinção da linhagem hominídea de outras não está simplesmente na cultura em si, mas sim na acumulação cultural possibilitada pela imitação fidedigna sustentada em uma base material (genes e ambiente), levando em consideração a ação conjunta de várias forças (forças aleatórias, forças atuando na tomada de decisões e a seleção natural) ${ }^{24}$.

Seguindo essa análise comparativa entre PE e TDH, há que se considerar a diferença entre seleção natural e transmissão enviesada, em que nesta última o critério da preferência por uma variação cultural em detrimento de outras funciona como critério primaz, enquanto que na seleção natural a adoção de certas variantes culturais modificam as vidas dos indivíduos que as adotaram, aumentando a probabilidade de esses indivíduos serem imitados. Novamente, a TDH se mostra distinta da PE, por considerar que a seleção natural atua diretamente sobre as variantes culturais, e não apenas de forma indireta (por adaptações biológicas individuais, somente) ${ }^{25}$.

Outra questão importante de se mencionar é que a TDH rejeita a tese do grande erro da PE. Segundo essa tese, nossa psicologia seria adaptada às condições de vida outrora estabelecidas no Pleistoceno, sendo que atualmente - na vida pós-moderna industrial - essa psicologia mostrar-se-ia maladaptativa. Ao invés disso, a TDH diz que tais "mal-adaptações" não são propriamente erros de nossa psicologia (como afirma a PE), mas subprodutos inevitáveis de nossa evolução cultural, haja vista a evolução dar-se tanto de modo vertical, horizontal e oblíquo. Desse modo, essas mal-adaptações seriam explicadas com base na aprendizagem social por imitação ${ }^{26}$. Portanto, as explicações providas pela TDH permitem o estudo do comportamento humano de um modo naturalista, porém não-reducionista. No caso da religião, esta seria então um fenômeno natural e complexo - não redutível a elementos puramente genéticos ou simplesmente subproduto desses, como queriam os psicólogos evolutivos - mas os aspectos evolutivos culturais seriam igualmente marcantes na explicação do comportamento.

Na próxima seção, abordaremos a crítica de Plantinga ao naturalismo, na tentativa de expressar, ao final, um juízo adequado referente à questão de se o argumento de Plantinga é capaz de suplantar (ou pelo

\footnotetext{
${ }^{24}$ Para uma abordagem detalhada sobre essas forças, conferir ABRANTES, P. C. C.; ALMEIDA, F. P. L. de. "Evolução humana: a teoria da dupla herança". In: ABRANTES, P. C. C. (org.). Filosofia da Biologia. Porto Alegre: Artmed, 2011.

${ }^{25}$ ABRANTES, P. C. C.; ALMEIDA, F. P. L. de. "Evolução humana: a teoria da dupla herança". In: ABRANTES, P. C. C. (org.). Filosofia da Biologia. Porto Alegre: Artmed, 2011, p. 274.

${ }^{26}$ Transmissão vertical é a transmissão genética entre aparentados; transmissão horizontal é a transmissão de variantes culturais entre indivíduos não aparentados da mesma geração e transmissão oblíqua é a transmissão de variantes culturais entre indivíduos não aparentados de gerações distintas. Cf. ABRANTES, P. C. C.; ALMEIDA, F. P. L. de. "Evolução humana: a teoria da dupla herança". In: ABRANTES, P. C. C. (org.). Filosofia da Biologia. Porto Alegre: Artmed, 2011, p. 283-284.
}

\begin{tabular}{|c|c|c|c|c|c|}
\hline intuitio & $\begin{array}{c}\text { ISSN } \\
1983-4012\end{array}$ & Porto Alegre & Vol.8 $-\mathrm{N}^{\mathrm{o}} .1$ & $\begin{array}{c}\text { Junho } \\
2015\end{array}$ & p.261-275 \\
\hline
\end{tabular}


menos desestabilizar) a proposta da TDH, no que tange à justificação do comportamento da pessoa humana.

\section{A crítica de Plantinga à associação do naturalismo com a evolução ${ }^{27}$}

Para desenvolver sua crítica, Plantinga ocupar-se-á com a arguição sobre a confiabilidade de nossas faculdades cognitivas, as quais são responsáveis pela produção de nossas crenças e conhecimento. Em condições normais de funcionamento do nosso aparato cognitivo - excluído os casos em que há alguma deficiência física ou psíquica - é razoável pensar que nossas faculdades mentais são confiáveis, diante de certas situações. No que tange à perspectiva teísta, Deus criou-nos a sua imagem e semelhança, de modo que a confiabilidade de nossas faculdades cognitivas esteja garantida em razão de nossa semelhança com Deus (se Deus é um ser que tem conhecimento, então semelhantemente eu sou um ser que tem conhecimento de algo; e assim por diante). Plantinga então questiona se a confiabilidade de nosso aparto cognitivo pode ser sustentada quando uma entidade transcendente (Deus) não conta na explicação, ou seja, caso assumamos a conjunção naturalismo-evolução, a confiabilidade de nossas mentes ainda está $\operatorname{assegurada}^{28}$ ?

Para o naturalismo, nossas faculdades cognitivas surgiram por mecanismos e processos propostos pela teoria da evolução contemporânea. A maioria dos naturalistas acredita que nossas faculdades cognitivas não têm como função principal gerar crenças verdadeiras ou verossímeis, mas tão somente promover a sobrevivência e o processo reprodutivo. Ou seja, nosso comportamento é adaptativo e, por isso, não necessita de qualquer garantia de verdade ou falsidade das nossas crenças, mas tão somente que nossas crenças sejam úteis em determinados ambientes - isso por que é indiferente para seleção natural que tais crenças tenham valoração lógica qualquer ${ }^{29}$.

Plantinga constrói um argumento em que a dita "dúvida de Darwin"30 figura como primeira premissa. A “dúvida de Darwin” é a tese de que a evolução naturalista põe em questão a produção de crenças verdadeiras por nossas faculdades cognitivas. Nas palavras de Plantinga, a evolução mostra-se desarrazoada quando a probabilidade condicional de que as nossas faculdades cognitivas sejam confiáveis, dado o naturalismo, é baixa. Simbolicamente, a premissa seria expressa da seguinte forma: $P(R / N \& E)$ é baixa; onde ' $R$ ' é a confiabilidade de nossas faculdades cognitivas, ' $N$ ' é o naturalismo e ' $E$ ' é a proposição que diz que nossas faculdades cognitivas e nós próprios viemos a ser com tais conforme os

\footnotetext{
${ }^{27}$ Há, no mínimo, quatro versões deste argumento (ver nota 1 ).

${ }^{28}$ PLANTINGA, A. Where The Conflict Really Lies. New York: OUP, 2011, p. 310-313.

${ }^{29}$ PLANTINGA, A. Where The Conflict Really Lies. New York: OUP, 2011, p. 315.

${ }^{30}$ Cf. MEYER, S. C. Darwin's doubt: Explosive Origin of Animal Life and the Case for Intelligent Design. New York: HarperOne, 2013.
}

\begin{tabular}{|c|c|c|c|c|c|}
\hline intuitio & $\begin{array}{c}\text { ISSN } \\
1983-4012\end{array}$ & Porto Alegre & Vol.8 $-\mathrm{N}^{\mathrm{o}} .1$ & $\begin{array}{c}\text { Junho } \\
2015\end{array}$ & p.261-275 \\
\hline
\end{tabular}


termos da teoria da evolução contemporânea. A força dessa premissa está no fato de que se $N \& E$ for verdadeiro, então a probabilidade $P(R / N \& E)$ é baixa. Consequentemente, temos um anulador para a proposição ' $R$ ' e para a proposição de que as nossas próprias faculdades cognitivas são confiáveis. Vejamos em pormenor como Plantinga chega a esta conclusão ${ }^{31}$.

Para seguir na sua argumentação, Plantinga precisa definir o que se entende por naturalismo e quais as suas principais características. Assim, uma possível definição seria a de que o naturalismo é uma filosofia segundo a qual não existe nenhuma pessoa como Deus, ou seja, nenhuma forma de entes ou “eus” imateriais - tese esta já levantada pela PE. Nesse sentido, os naturalistas são tomados como materialistas, onde nós, seres humanos, não dispomos de uma alma (eu imaterial), mas sim uma mente que decorre de um cérebro e de funções neurológicas. Outra característica importante dos naturalistas é que eles também endossam a teoria darwiniana da evolução. Se se aceita essas considerações, temos assim a imbricação entre naturalismo e evolução, cuja consequência imediata é a suspeita a respeito de se nossas faculdades cognitivas, em sua maior parte, produzem crenças verdadeiras ${ }^{32}$.

Diante dessa situação, é normal perguntarmos que tipo de coisa seriam as crenças para os naturalistas? Pela análise de Plantinga, elas seriam, por um lado, estruturas neurais - onde se tem inputs em algumas partes do sistema nervoso e outputs em outras partes - e propriedades eletroquímicas ou neurofisiológicas (propriedades NF), de modo a estimularem músculos e glândulas para realizar alguma ação corporal. Ora, mas é-nos sabido que crenças veiculam conteúdos, no sentido de que a minha crença de que o naturalismo é uma teoria metafísica veicula o conteúdo exprimido pela proposição “o naturalismo é uma teoria metafísica". O "conteúdo" de uma crença não é algo físico, mas sim um evento mental, que, portanto, deveria ser avaliado segundo seu critério de verdade - critério este não aceitável pelo naturalismo. Dessa forma estas duas componentes: I) propriedades NF e II) conteúdo (propriedades físicas e propriedades mentais, respectivamente), têm de estar, de alguma maneira, relacionadas. Se se considera que propriedades mentais são inteiramente (e não mais que) comportamento de um imenso conjunto de células nervosas e suas moléculas associadas, estamos diante de um naturalismo redutivo a propriedades físicas (propriedades NF). Se o naturalismo é do tipo não-redutivo, estamos diante de propriedades de conteúdo, as quais não são redutíveis a propriedades NF, mas que são determinadas por [ou sobrevêm] a propriedades $\mathrm{NF}^{33}$. Isso nos mostra que, independente de ser ou não reducionista, o naturalismo reza que propriedades mentais são determinadas por propriedades físicas.

Associando essa ideia (propriedades mentais são determinadas por propriedades físicas) à da evolução, na medida em que se sobe na escala filogenética, percebem-se variados graus de complexidade das estruturas neurais dos seres vivos, alguns com nenhum desenvolvimento de crenças (exemplo, as

\footnotetext{
${ }^{31}$ PLANTINGA, A. Where The Conflict Really Lies. New York: OUP, 2011, p. 316-317.

${ }^{32}$ PLANTINGA, A. Where The Conflict Really Lies. New York: OUP, 2011, p. 318-319.

${ }^{33}$ PLANTINGA, A. Where The Conflict Really Lies. New York: OUP, 2011, p. 320-322.
}

\begin{tabular}{|c|c|l|l|l|l|}
\hline intuitio & $\begin{array}{c}\text { ISSN } \\
1983-4012\end{array}$ & Porto Alegre & Vol.8 $-\mathrm{N}^{\mathrm{o}} .1$ & $\begin{array}{c}\text { Junho } \\
2015\end{array}$ & p.261-275 \\
\hline
\end{tabular}


bactérias) até outros com estruturas extremamente requintadas, capazes de produzir crenças (exemplo, seres humanos). Assim, o que irá determinar se uma estrutura neural é capaz ou não de adquirir crenças será o nível de complexidade das propriedades NF que tal estrutura for dotada, além do fato de que tais propriedades devem ser adaptativas, para favorecer a seleção natural. Considerando isso, Plantinga pergunta qual a probabilidade (dados naturalismo e evolução) de que nossas faculdades cognitivas (o conteúdo de nossas crenças associado às nossas estruturas neurais) sejam de fato confiáveis (produzem realmente conteúdo verdadeiro a partir de crenças verdadeiras) $?^{34}$

Portanto, a probabilidade $\mathrm{P}(\mathrm{R} / \mathrm{N} \& \mathrm{E})$ é baixa em razão das propriedades $\mathrm{NF}$ de uma crença ser adaptativas (no sentido de produzirem comportamento adaptativo). Se isso é o caso, tais propriedades também determinam as propriedades de conteúdo. Ora, os princípios da seleção natural seriam a reprodução e a sobrevivência. Logo, é irrelevante, do ponto de vista adaptativo, o valor-verdade de uma crença. Em outros termos, a probabilidade de um conteúdo de crença ser verdadeiro é de $50 \%$. Consequentemente, a probabilidade de que nossas faculdades cognitivas sejam confiáveis também é baixa, pois a expectativa de o número de crenças verdadeiras superarem o de crenças falsas é pequena ${ }^{35}$.

Ser ou não ser verdadeira, eis a questão. Para Plantinga, uma crença verdadeira certamente facilita a ação adaptativa. Poder-se-ia encontrar inúmeros exemplos que corroboram essa ideia ${ }^{36}$. A maioria das pessoas acredita [e estão certas nisso] que nossas faculdades cognitivas são confiáveis, em grande parte, em razão de experimentarem que crenças verdadeiras causam melhoramento adaptativo (pois crenças verdadeiras levam a ações bem sucedidas e crenças falsas prejudicam o comportamento adaptativo, em sua maioria). Já para o naturalismo, o comportamento decorrente de uma crença é causado não por conta de um conteúdo particular desta, mas sim em virtude das propriedades NF que regem a crença ${ }^{37}$.

Diante disso, alguém que aceite o naturalismo e também vê que $P(R / N \& E)$ é baixa, constrói um “anulador para a proposição $R$ ” (quer dizer, torna $R$ : “a confiabilidade em nossas próprias faculdades cognitivas", inaceitável, racionalmente). No entanto - e esta é a ideia central de Plantinga - deve-se observar que se tenho a anulação de $R$ (se minhas faculdades cognitivas estão sob suspeitas e não merecem confiança), então não posso mais sustentar crença alguma minha - inclusive a proposição inicial “tenho um anulador para $R$ ”. Esse argumento parece válido devido a minha crença em $R$ ser básica, pois quaisquer crenças minhas tem como pressuposto $R$ (todas minhas crenças verdadeiras dependem de eu confiar em minhas próprias faculdades cognitivas). Portanto, $R$ é pressuposto para todas as outras crenças.

\footnotetext{
${ }^{34}$ PLANTINGA, A. Where The Conflict Really Lies. New York: OUP, 2011, p. 324.

${ }^{35}$ PLANTINGA, A. Where The Conflict Really Lies. New York: OUP, 2011, p. 330-334.

${ }^{36}$ Uma gazela que equivocadamente crê que leões são amigáveis, não ficará por muito tempo neste mundo.

${ }^{37}$ PLANTINGA, A. Where The Conflict Really Lies. New York: OUP, 2011, p. 335-336.
}

\begin{tabular}{|c|c|c|c|c|c|}
\hline intuitio & $\begin{array}{c}\text { ISSN } \\
1983-4012\end{array}$ & Porto Alegre & Vol.8 $-\mathrm{N}^{\mathrm{o}} .1$ & $\begin{array}{c}\text { Junho } \\
2015\end{array}$ & p.261-275 \\
\hline
\end{tabular}


Esta é a segunda premissa do argumento de Plantinga: qualquer um que aceita $N \& E$ e vê que $P(R / N \& E)$ é baixa tem um anulador para $R^{38}$.

A terceira premissa é fácil de explicitá-la, dada a explicação nossa até agora. Qualquer um que tenha um anulador $R$ terá também um anulador para qualquer outra crença que ele pense ter, inclusive a própria conjunção $N \& E$, isso porque qualquer crença é produzida pelas faculdades cognitivas. Ora, é muito improvável que alguém que admita esse anulador para $R$ abandone todas (ou pelo menos as principais) de suas crenças. Ora, pode você, estando no alto de um prédio de 100 andares e acreditando que se saltar dali irá chocar-se-á contra o chão e possivelmente morrerá, invocar um anulador para $R$ a fim de executar o seu salto? Se você é um naturalista, você pode.

É considerando esse ceticismo extremo do naturalismo que Plantinga formula sua quarta premissa: se alguém que aceita $N \& E$ adquire, a partir daí, um anulador para $N \& E, N \& E$ é por si mesma autoanuladora e não pode ser racionalmente aceita. Normalmente, um naturalista pode argumentar que anuladores $A^{\prime}$ possuem respectivos anuladores $A$ "' para si e que nossas crenças não são em geral equivocadas. Apesar de isso parecer razoável, o naturalista terá um anulador não anulável para $N \& E$, pois a razão mesma para desconfiar de nossas faculdades cognitivas será uma razão para desconfiar das faculdades que produzem crenças ${ }^{39}$.

Houve quem criticou este argumento de Plantinga sobre a associação entre naturalismo e evolução, buscando ou falsear ou mitigar, ao menos, alguma das premissas de tal argumento. Podemos citar: Ginet (1995), Fitelson \& Sober (1998), Bergmann (2002), Fales (2002), O'Connor (2002), Ramsey (2002), Sosa (2002), Talbott (2002), Van Cleve (2002), Swinburne (2004), Dennett (2007), Dawkins (2008), Churchland (2009), Childers (2011). Dessas críticas, as construídas por Ramsey e Swinburne são as que consideramos mais plausíveis, de modo que as respostas de Plantinga a estas não parecem satisfatórias ${ }^{40}$.

\section{Considerações finais}

Como vimos, a tese primária de Plantinga é de que entre ciência e religião o conflito existente é superficial, mas a concórdia é profunda. Por outro lado, entre naturalismo e ciência, o que há de concórdia é apenas superficial, mas o conflito é profundo. Especificamente, o naturalismo estaria em conflito com a

\footnotetext{
${ }^{38}$ PLANTINGA, A. Where The Conflict Really Lies. New York: OUP, 2011, p. 339-340.

${ }^{39}$ PLANTINGA, A. Where The Conflict Really Lies. New York: OUP, 2011, p. 341-347.

${ }^{40}$ Neste artigo, não analisaremos essas críticas a Plantinga, haja vista nosso trabalho ser bem menos pretencioso, sendo que tal análise apenas oneraria este artigo. Portanto, nosso objetivo aqui, mesmo que incipiente, é contribuir para o debate, com a introdução de elementos da TDA nesta seara. Para uma exposição adequada dessas críticas, bem como as respectivas respostas de Plantinga, conferir dissertação de mestrado de SILVEIRA, Rodrigo Rocha. Natureza, ciência e religião: uma avaliação do naturalismo. Brasília: UnB, 2014.
}

\begin{tabular}{|c|c|c|c|c|c|}
\hline intuitio & $\begin{array}{c}\text { ISSN } \\
1983-4012\end{array}$ & Porto Alegre & Vol.8 $-\mathrm{N}^{\mathrm{o}} .1$ & $\begin{array}{c}\text { Junho } \\
2015\end{array}$ & p.261-275 \\
\hline
\end{tabular}


teoria da evolução, de modo tal que seria impossível aceitar os dois (naturalismo e evolução) simultaneamente $^{41}$. Observamos ainda que a crítica de Plantinga à conjunção $N \& E$ é um problema que tanto a psicologia evolutiva quanto a teoria da dupla herança devem considerar de antemão em suas abordagens. Isso porque uma psicologia evolutiva que adote conteúdos da mente (crenças) como significando subproduto de uma realidade única e material, está obrigada a responder sobre a confiabilidade das faculdades cognitivas. Analogamente (e embora a teoria da dupla herança tenha incrementado a discussão sobre a naturalização de processos mentais), essa teoria também tem de pressupor certa confiabilidade às faculdades cognitivas, para que se possa falar em uma evolução cultural, pois que a acumulação cultural depende disso.

Vimos também que a PE, como ciência naturalista, acarreta um conflito superficial entre ciência e religião. A religião seria um subproduto decorrente do processo evolutivo de nossas capacidades cognitivas e recheada de noções e objetos contra-intuitivos/contra-factuais, cujo único interesse desse fenômeno (se se admite algum fenômeno religioso) seria tão somente maximizar a sobrevivência e a reprodução humana. A pergunta (e resposta) sublimada na PE parece ser a mesma do naturalismo [materialista]: a quem a seleção natural favorece? Ao gene. Contudo, diz-se tal conflito superficial por que este não anula a possibilidade de a crença teísta ser verdadeira, visto que a ação de Deus no mundo permanece ainda viável. Daí a crítica dos teóricos da dupla herança, pois a PE ao tentar explicar a cultura humana toma como guia a seleção natural genética. A TDH considera esse aspecto da PE insuficiente para explicar o comportamento humano, e toma como ponto nevrálgico a acumulação cultural possibilitada pela imitação fidedigna, onde a seleção natural atuaria diretamente sobre as variantes culturais. Ou seja, as variantes culturais transmitir-se-iam verticalmente (transmissão genética), horizontalmente (entre indivíduos não aparentados da mesma geração) e obliquamente (entre indivíduos não aparentados de gerações diferentes). Nesse sentido, mostrou-se um conflito entre TDH e PE, pois esta última endossa que a seleção natural age apenas indiretamente sobre a cultura (subproduto da seleção genética). Assim, tomando a TDH como uma teoria de maior escopo do que a PE, o comportamento humano e a atuação humana enquanto ser cultural (e, extensivamente, como homo religiosus) estaria determinado pela $i$ ) genética e ii) pela evolução no nível da cultura. A TDH seria então uma construção teórica naturalista não reducionista ao nível dos genes.

Por outro lado, também vimos que o naturalismo associado à ciência (de forma mais específica à teoria da evolução contemporânea) acarreta um conflito profundo com a ciência, pois põe em cheque a confiabilidade de nossas faculdades cognitivas. Especificamente, vimos o problema de se tomar as faculdades cognitivas do ponto de vista material. O naturalismo assume fortemente essa posição quando ratifica a tese de que propriedades mentais são determinadas por propriedades físicas (propriedades NF).

${ }^{41}$ PLANTINGA, A. Where The Conflict Really Lies. New York: OUP, 2011, p. 307-310.

\begin{tabular}{|c|c|c|c|c|c|}
\hline intuitio & $\begin{array}{c}\text { ISSN } \\
1983-4012\end{array}$ & Porto Alegre & Vol.8 $-\mathrm{N}^{\mathrm{o}} .1$ & $\begin{array}{c}\text { Junho } \\
2015\end{array}$ & p.261-275 \\
\hline
\end{tabular}


Plantinga mostrou-nos através de uma argumentação bastante consistente que se de fato repousar a dúvida sobre nossas faculdades cognitivas, no que tange à sabença de elas produzirem ou não crenças (conteúdo), é fácil concluir que qualquer conteúdo de crença estará sob suspeita - o que inviabilizaria todo tipo de pensamento racional.

A relação entre TDH e religião (sendo esta tomada como fenômeno cultural) mostra-se conflituosa devido ao naturalismo implícito na TDH. Vimos que a TDH tenta explicar o desenvolvimento cultural considerando que as variantes culturais estão em evolução vertical, horizontal e obliquamente. No que tange à evolução horizontal e oblíqua (a evolução propriamente cultural), é necessário sustentar a confiabilidade nas faculdades cognitivas, pois, caso contrário, parece ser irracional e anti-intuitivo sustentar uma evolução nesses níveis.

Se aceitarmos que o argumento de Plantinga está correto, ou seja, que a conjunção do naturalismo com a evolução irá implicar na anulação da confiabilidade de nossas faculdades racionais e, por extensão, de todos nossos juízos a respeito da verdade ou falsidade de qualquer proposição - tanto a PE como a TDH terão de lidar com essa objeção. Em contraponto, a crença teísta tem se mostrado bastante coerente com a teoria darwinista contemporânea (e com a ciência em geral), sem causar conflitos insuperáveis ou antirracionais, sejam científicos ou filosóficos.

\section{Referências}

ABRANTES, P. C. "A psicologia de senso comum em cenários para a evolução da mente humana”. In: ManuscritoRev. Int. Fil., São Paulo, Vol. 29: n.1, 2006, p. 185-257.

, P. C. C.; ALMEIDA, F. P. L. de. "Evolução humana: a teoria da dupla herança". In: , P. C. C. (org.). Filosofia da Biologia. Porto Alegre: Artmed, 2011. 326p.

, P. C. C.; _ F. P. L. de. "A teoria da dupla herança e a evolução da moralidade". In: Principia, Florianópolis, Vol. 16, n. 1, 2012, p. 1-32.

ATRAN, S. In Gods We Trust. Oxford: Oxford University Press, 2006. 348p.

BERGMANN, Michael. "Commonsense Naturalism". In: BEILBY, James (org). Naturalism defeated?: Essays on Plantinga's Evolutionary Argument Against Naturalism. Ithaca: Cornell University Press, 2002, p. 61-90.

BOYER, Pascal. Religion Explained. New York: Basic Books, 2001. 384p.

CHILDERS, Geoff. "What's wrong with the evolutionary argument against naturalism?". International Journal for Philosophy of Religion. v. 69, n. 3, 2011, p. 193-204. http://dx.doi.org/10.1007/s11153-010-9272-3

CHURCHLAND, Paul. "Is evolutionary naturalism epistemically self-defeating?". Philo. vol. 12, n. 2, 2009, p. 135141. http://dx.doi.org/10.5840/philo200912210

DAWES, G. W. Theism and explanation. New York: Routledge, 2009. 211p.

DAWKINS, Richard. O relojoeiro cego. Trad. Isabel Arez. Lisboa: Edições 70, 1986. 377p.

, Richard The God delusion. Nova Iorque: Houghton Mifflin, 2008. 463p.

DENNETT, Daniel. Breaking the spell: religion as a natural phenomenon. Nova Iorque: Penguin, 2007. 448p.

DUNBAR, R. I. M.; BARRET, L. Oxford Handbook of Evolutionary Psychology. New York: Oxford University Press Inc., 2007. 720p.

FALES, Evan. "Darwin's doubt, Calvin's calvary". In: BEILBY, James (org). Naturalism defeated?: Essays on Plantinga's Evolutionary Argument Against Naturalism. Ithaca: Cornell University Press, 2002, p. 43-58.

FITELSON, Branden; SOBER, Elliott. "Plantinga's probability argument against evolutionary naturalism". Pacific Philosophical Quarterly. n. 79, 1998, p. 115-129.

\begin{tabular}{|c|c|l|l|l|l|}
\hline intuitio & $\begin{array}{c}\text { ISSN } \\
1983-4012\end{array}$ & Porto Alegre & Vol.8 $-\mathrm{N}^{\mathrm{o} .1}$ & $\begin{array}{c}\text { Junho } \\
2015\end{array}$ & p.261-275 \\
\hline
\end{tabular}


FLAVELL, J. La psicologia evolutiva de Jean Piaget. Trad.: Marie T. Cevasco. Buenos Aires: Paidós, 1968. 484p. GINET, Carl. "Comments on Plantinga's Two-Volume Work on Warrant". Philosophy and Phenomenological Research. v. 55, n. 2, jun 1995, p. 403-408. http://dx.doi.org/10.2307/2108558

GOLD, S. J.; LEWONTIN, R. C. "The Spandrels of San Marco and the Panglossian Paradigm: A Critique of the Adaptationist Programme". In: Proc. R. Soc. B, n. 205, London, 1979, p. 581-598. http://dx.doi.org/10.1098/rspb.1979.0086

HAUGHT, J. F. "Is nature enough? No". In: Zygon, Chicago, n. 38, 2003, p. 769-782. http://dx.doi.org/10.1111/j.1467-9744.2003.00538.x

MEYER, S. C. Darwin's doubt: Explosive Origin of Animal Life and the Case for Intelligent Design. New York: Harper USA, 2013. 498p.

O'CONNOR, Timothy. A house divided against itself cannot stand. In: BEILBY, James (org). Naturalism defeated?: Essays on Plantinga's Evolutionary Argument Against Naturalism. Ithaca: Cornell University Press, 2002, p. 129134.

PINKER, Steven. Como a mente funciona. São Paulo: Companhia das Letras, 1998. 666p.

PLANTINGA, Alvin. “An Evolutionary Argument against Naturalism”. Logos, v. 12, 1991, p. 27-48. Alvin. Warrant and Proper Function. Oxford: Oxford University Press, 1993. 256p. , Alvin. "Introduction". In: BEILBY, James (org). Naturalism Defeated?: Essays on Plantinga's Evolutionary Argument against Naturalism. Ithaca: Cornell University Press, 2002, p. 1-12. , Alvin; TOOLEY, Michael. Conhecimento de Deus. $1^{a}$ Edição. São Paulo: Vida Nova, 2014. 336p.

, Alvin. Where The Conflict Really Lies. New York: Oxford University Press Inc., 2011. 359p.

RAMSEY, William. "Naturalism defended". In: BEILBY, James (org). Naturalism defeated?: Essays on Plantinga's Evolutionary Argument Against Naturalism. Ithaca: Cornell University Press, 2002, p. 15-29.

RUBEN, D. H. (org.), Explanation. New York: Oxford University Press Inc., 2004. 376p.

RUSE, D.; WILSON, E. O. "The Evolution of Ethics". In: HUCHINGSON, James E. (org.). Religion and the Natural Science: The Range of Engagement. San Diego: Harcourt Brace, 1993. 422p.

SEGERSTRALE, U. Defenders of the Truth: The Battle for Science in the Sociobiology Debate and Beyond. New York: Oxford University Press Inc., 2000. 504p.

SOSA, Ernest. "Plantinga's evolutionary meditations". In: BEILBY, James (org). Naturalism defeated?: Essays on Plantinga's Evolutionary Argument Against Naturalism. Ithaca: Cornell University Press, 2002, p. 91-102.

STARK, R.; BAINBRIDGE, W. S. Uma teoria da religião. São Paulo: Paulinas, 2009. 496pp.

SWINBURNE, Richard. The existence of God. $2^{\mathrm{a}}$ edição. Oxford: Oxford University Press, 2004. 384p.

VAN CLEVE, James. “Can atheists know anything?”. In: BEILBY, James (org). Naturalism defeated?: Essays on Plantinga's Evolutionary Argument Against Naturalism. Ithaca: Cornell University Press, 2002, p. 103-125.

Recebido em: 23/09/2014

Aprovado para publicação em: 23/04/2015

\begin{tabular}{|c|c|l|l|l|l|}
\hline intuitio & $\begin{array}{c}\text { ISSN } \\
1983-4012\end{array}$ & Porto Alegre & Vol.8 $-\mathrm{N}^{\mathrm{o}} .1$ & $\begin{array}{c}\text { Junho } \\
2015\end{array}$ & p.261-275 \\
\hline
\end{tabular}

